\title{
The Binary Oppositions in Joseph Conrad's Novel Heart of Darkness
}

\author{
Asst. Prof. Huda Kadhim Alwan \\ MOHE\&SR / Dir. of Scholarships and Cultural \\ Relations \\ hudayoyo.hm@Gmail.com
}

DOI: https://doi.org/10.36473/ujhss.v60i4.1837

Received: $20 / 12 / 2020$

Accepted: 2/2/2021

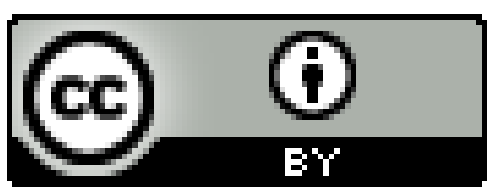

This work is licensed under a Creative Commons Attribution 4.0 International License

\section{$\underline{\text { Abstract }}$}

The novel Heart of Darkness is regarded as one of Joseph Conrad's highly skilled works and seen as an important tale written between the years of 1898 - 1899, and also viewed as an assault on imperialism and unethical behaviors of the European colonizers in Africa in the nineteenth century. The novel displays the author's humanity towards the crimes of the colonists and imperialists throughout the world. In Heart of Darkness, Conrad shows the cruelty of colonialism in Africa through his major character, Charlie Marlow, who realizes the cruel manners of Belgian colonialism during his journey to the Congo looking for the European ivory agent, Kurtz. This novel is a combination of two opposite things. It exposes the author's viewpoint regarding the ethics of the Europeans and the Africans. This research concentrates on the binary oppositions in Heart of Darkness through Marlow's journey to Africa and exposes Marlow's struggle between his human nature and his beliefs and replies whether his conflict will be effective and bring good results or negative.

Keywords: Joseph Conrad, colonialism, imperialism, binary oppositions, darkness. 


\author{
المتضادات الثنائية في رواية جوزيف كونراد قلب الظلام \\ أ.م هدى كاظم علوان \\ وزارة التعليم العالي والبحث العلمي / دائرة البعثات والعلاقات التقافية
}

hudayoyo.hm@Gmail.com

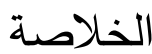

تُعدُ رواية جوزيف كونراد قلب الظلام واحدة من أعماله الماهرة جداً وتمت رؤيتها قصة مهمة كُتبت بين السنوات 1898 - 1899 كما تمت رؤيتها أيضاً باعتبارها هجوما على هنى

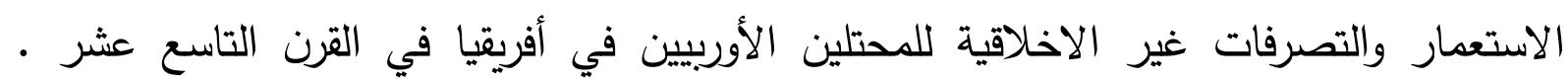

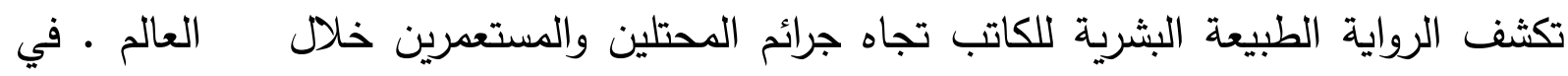
قلب الظلام يعرض كونراد وحشية الاحتلال في أفريقيا من خلال شخصيته الرئيسة جارلي مارلو الذي ادرك الأساليب الوحشية للاحتلال البلجيكي خلال رحلته إلى الكونغو بحثاً عن الوكيل

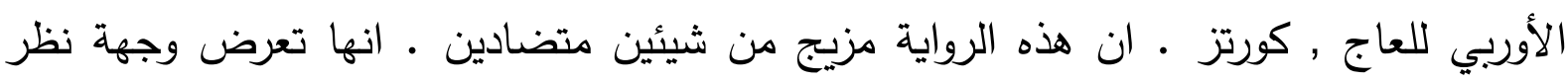
الكاتب فيما يتعلق باخلاقيات الأوربيين والأفارقة.

يركز هذا البحث على المتضادات الثنائية في قلب الظلام التهات خلادل رحلة مارلو إلى أفريقيا ويعرض صراع مارلو بين طبيعته البشرية ومعتقداته ويُجيب فيما إذا كان هذا الصراع مؤثر لئر

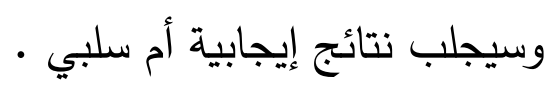

الكلمات المفتاحية : جوزيف كونراد ، الاحتلال ، الاستعمار ، المتضادات الثنائية ، الظلام .

\section{Introduction}

Joseph Conrad (1857 - 1924) is a forerunner of a modern novel. His life is closely linked with his novels. He came from a patriot family. His father was dismissed to another nation "Vologda, Russia" thereafter to "Chernikhov". He practiced the unfairness of the weak nations. Conrad saw these things through the suffering of his parents who were dismissed to Ukraine because of political matter. His energetic spirit loves exciting experiences. This spirit made him go on a journey to France on a sea voyage. His practice on the French ship was short. He joined the British Merchant Marin service regardless of speaking no English at that time. That supplies him with substances of his novels. Navy made him view various continents, Asia, Africa, Australia, and South America. The life of the sea was hard. The patriot's life is full of storms and danger. That has improved Conrad's realization of man and life and his relationship with people. Joseph Conrad is one of the most fascinating and significant 
modern novelists. His writing goes on to prepossess twenty-first century readers. The ascend of postcolonial studies has motivated new concerns in Conrad's topics of travel, exploration, and different racial struggle. These subjects are examined in his main works, Nostromo, Lord Jim, and Heart of Darkness in addition to his short stories (Peters, 2006, p. i).

In May 1890, Conrad started on one of the most significant trips of his life when he went on a voyage to Congo to agree on his job. His practice is registered partially in his "Congo Diary," yet it had as well as turned into the base for "An Outpost of Progress" and his principal famous story Heart of Darkness. In June, he reached the Congo River and started his journey up the river, progressing from Bowa to Matadi. Through his lodge, he became intimate with Roger Casement, who afterward became well-known when he showed the cruelties happening in the Belgian Congo. Conrad formed a great accord of avarice, dissipation, and bewilderment despite the portrayal of the colonial initiative in Europe as a humane attempt. While the captain was ill, Conrad was demanded to capture the direction of the Roi des Belges tentatively, and the several days he represented as interchange captain comprise Conrad's merely direction in Africa. The resumption trip took an ill worker, Gorge Antonie Klein, who died on road. Klein became one of the patterns for Kurtz in Heart of Darkness. Throughout the following few months, Conrad traveled during the Congo on company work, and manifests to have tolerated a perfect accord from sick health. Returning to Europe at the end of January 1891, he invalided home. The practice of Conrad in the Congo had a massive effect on him. It would influence him for the remains of his life, and to the same extent; anything else affected his prospect on civilizations and human presence itself, despite its connected briefness. His critique of the harms and confusion he testified was relentless as appeared in his different writings on the theme (Peters, 2006, p. 4). Conrad surpassed several months of healing his psychological and physical health after returning from the Congo.

This novella is interested in the issue of colonization. The English novel does not distribute with one theme, but with many issues. The novelist attempts to pursue the major events in the world like the First and Second World War. The most significant thing in this novel is the journey made for Belgian Congo. This country was under the control of white Belgium. There he witnessed the oppression of the white man imposed on the poor people. This polish writer, who gained British Nationality after a long time, tackles the sea stories and its danger. Marlow is the narrator of his many 
novels. He becomes the sound and instrument through which the events of his novels conveyed. The novel focuses on the individuals' social life in a society. "Heart of Darkness is more symbolic than realistic, while in Emily Bronte's Wuthering Heights, the real and symbolic are equally important" due to Goonetilleke.(Qasaimeh \& Joshi, 2009, p. 45) Marlow does not explore inside attainable zones, as his excursion in the Congo is along a stream. However, V. S. Naipaul thinks that "the river remains not merely the great highway of the country, but at the heart of its culture". Marlow is not a legend such as Fielding in E. M. Foster's A Passage to India. He performs mainly as devices during which the writer transfers the complications of rudimentary culture and Western civilization. Conrad intervenes onto the Congo, and the imperial confusions of Belgium in a universal illumination (Qasaimeh \& Joshi, 2009, pp. 45 , 46).

Rizzo (2003) states that by the nineteenth century, utmost Europeans grasped several conceited positions considering themselves. Europeans defined themselves as a technologically and intellectually superior race, and they used this arrogant position to vindicate the colonial control of those less "civilized". Due to George Fredrickson, whatever their functional determinations or intentions, the conquerors did not face the native people without definite presuppositions concerning their nature that helped to form the way they continued their aims. Notions of 'Savagery ' advanced in the sixteenth and seventeenth centuries and became the general estate of western European culture. These doctrines were not so far racist in the nineteenth-century sense of the term because they were not founded on an evident belief of authentic or biological disparity, but they could supply an equal foundation for taking into account some classifications of human beings inferior to others in manners that made it legal to patronize them variously from Europeans (p. 1).

In European countries and the United States; white individuals regarded themselves as better than dark individuals that made numerous troubles in similar social orders. On top of that, trade and industrialization drove numerous European nations to embrace wide range sorts of racism to fulfill their aims, as well as contested with one another to gain more regions in another country. Therefore, Europeans began to embrace recent doctrines which corroborated the white races anywhere and refused the non-white races' superiority that indicates black or brown persons. In the nineteenth century, the requirement of Europeans for prosperity and unrefined fabrics conducted them to seek regions in India or Africa. Therefore, they began to construct themselves like large forces. Several authors from Europe, and 
the British specially, got the chance to portray colonialism and racism world particularly throughout the nineteenth century. Those English authors depicted the modern imperialism world that was happened through the British contest for power and trade (Sharmin, 2018, p. 1).

The novel has been known by increasing critics as principally and particularly extremely of a blended object; a story filled with vagueness and not settled oppositions. It rejects the perfections for which the Europeans assert to come to Africa, for their light is one that together spreads light and kindles provincials. The novel continues lively, related, and real because of this vagueness and opposition. (Firchow, 2000, p. 26) The title of the novel has much physical and psychological significance. Conrad attempted to offer us the practices of the white man who is a possessor of civilization and how he manipulates the black man.

\section{Theoretical Framework}

Colonialism is the standpoint or exercise of gaining full or partial political rule over another country, conquering it with settlers, manipulating it economically (Mustafa, 2018, p. 1). The expression of colonialism is significant in realizing the particular shape of imposition for the culture which improved due to Europe enlargement onto the ultimate four hundred years. Even though numerous previous cultivations had colonies, and even though they understood their relationships together to be one of the major imperium in relationship to a perimeter of rural, minor, and atrocious cultures, several critical causes got in the Post-Renaissance structure of imperialism exercises. Edward Said shows the next differences: "Imperialism" signifies the exercise, the theory, and the actions of a controlling metropolitan center governing the aloof region. "Colonialism", which is a constant an outcome of imperialism, is the inserting of communities on the aloof region. The colonial communities ascend and diversity created by the enlargement of European society sequent the Renaissance offers why the expression colonialism has been viewed to be a different shape of the more common imperialism ideology. Even though Said's form which uses 'imperialism' for the ideological impose and ' colonialism' for the exercise, is a usually helpful difference, European colonialism in the Post-Renaissance world became a sufficient manner specified and historically special form of imperial enlargement to vindicate its recent usual practice as a special sort of political ideology (Ashcroft, Griffiths, \& Helen, 1995, pp. 45 , 46). 
The race's ideology was as well as a vital part of the structure and naturalization of the disparate type of highly intelligent relationships in colonies where secondary native individuals lived, or where the topic individuals were of various races. Race, itself, with its joining racism and racial bias, was broadly a result of a similar Post-Renaissance period, and vindication for the treating of subjugated people after the improvement of the slave exchange of the Atlantic Middle Passage from the late sixteenth century forwards. In such cases, the idea of the colonial universe became one of people inherently inferior not only aside from civilization and history, but standpoint pre-settled to inferiority. Their condition of being subject was not only an issue of gain and suitability but likewise could build as a normal condition. At the end of the nineteenth century, the existence of the appropriate race in the unrefined implementation of Social Darwinism and the notion of the ' evolution of mankind' improved and moved nearby association with the imperialism ideas (Ashcroft, Griffiths, \& Helen, 1995, pp. 46, 47).

By the end of the nineteenth-century in Britain, a regional plan for Empire's task was perceived as Victorian society defied growing internal conflict and separation (Disraeli's ' Two Nations '). The New Imperialism idea was in numerous approaches Disraeli's answer to his understanding of Britain; it was parted into two countries of poor and prosperous, nonindustrial and industrial. Beyond other social sections and classes in Britain, Empire turned into the main ideological unifier. It became the major symbol of national solidarity in front of revolution, and greatly discerned social menace of class disorder that had appeared in the postindustrial British society. Colonization occurred as fundamental methods of explaining the colonizer and the making of feeling of solidarity under variations such as fortune, and class, and among increasingly opposed industrialized cities' life which improved the fortune, and that of the conventional peasantry to which its recipients withdrew or relinquished. The colonialist device allowed a patriotic thought of progress for the colonized, through such figures as tree/branch, parent/child, etc., which in hypothesis permitted that at a coming time the inferior colonials might be advanced to the situation of the colonizer. Yet, practically this coming time was constantly without an end postponed. It is important that no society gained total liberty from the colonial device by the mandatory, energetic separation of the colonial force until it was induced by a large interior conflict for self-determination or, utmost generally, by prolonged and 
energetic fierce opposition by the colonized (Ashcroft, Griffiths, \& Helen, 1995, p. 49).

The Postcolonial identity of the colonized individuals has been declaimed by post-colonialism. The postcolonial hypothesis aims to reckon for the cultural, political, and social impacts of colonialism on colonized individuals. Edward Said, in Orientalism portrays that the third universe is inspired as a foreign "other" by the Europeans and exploitation of the Europeans is vindicated by them. Europeans have depicted east as an oriental universe, and they have depicted themselves as westerners. The major of the postcolonial hypothesis is Said's Orientalism, as declared by Moore Gilbert; Europeans have inspired "Oriental World". Westerner's submission of " others' is a merit of cultural control. Westerners separated the universe between "us" and "them", "white and black", "light and dark", "superior and inferior" and "first world and third world". They characterize European identity and culture are superior, and African identity and culture are inferior. (Fatima, Jamil, \& Hanif, 2015, p. 42)

European colonialism and imperialism elevated the priority of the European (white) over the non-European. To set European rule, culture was used to behold imperialism as a process to colonize Africans. In his Culture and Imperialism, Edward Said fetches forth the thought that colonial literary texts, one being Conrad's Heart of Darkness, "were immensely important in the formation of imperial attitudes, references, and experiences". Joseph Conrad has been one of the utmost disputable literary characters of his time. His dispute endures today and his work has made large assistance to the advancement of postcolonial studies (Aydin, 2018, p. 232).

Conrad's novel, immediately and circuitously, affected numerous postcolonial authors like Edward Said, Homi Bhabha, Chinua Achebe, and Gayatri Spivak. He wrote Heart of Darkness at a time of European colonial extension. Conrad's critics explain numerous various restraints to Heart of Darkness. It is plainly linked to the status each critic picks in the debate upon this novel. The variety of their criticism outcomes from the duality of Conrad's status as an author and his program to disputable matters of the nineteenth century, for instance, colonialism, imperialism, and racism. To some critics, the novel is an offensive on colonialism and imperialism, whilst for the others; Conrad supports too intensely racial ideologies of his time and of different critics (Aydin, 2018, p. 233).

Postcolonial studies include a wide scale of cultures and societies whose highly various employs of English words not merely alteration for a 
time yet as well as assume sprains of the state, area, category, and genus, tight appointments of these expressions can rarely demonstrate to utter power. Expressions such as ' ethnicity' and ' race ', for instance, have created comprehensive debate and discussion in human studies, however, in post-colonial session, these expressions supply a specific concentration for untwisting the complicated kind of colonial relationships of the kinds of binaries imperialism itself makes, and of the paths wherein active opposition perhaps pledged by post-colonial social orders (Ashcroft, Griffiths, \& Tiffin, 1998, p. 2).

Avrom Fleishman in Politics (1967) of Conrad presses that "In Africa as well as in the Indies, the disruptive effects of imperialism on native society were clear to Conrad". While former reviewers confirmed the white men manners' collapse dispatched to the orbits equipped with weapons and in an inspection of wealth, Fleishman explains the moral dissolution of Africans one time Europeans are free on them. Many ancestors of Fleishman had estimated that Heart of Darkness says however, imperialism decreases white messengers from a cultivated to a primal condition, departing them no preferable virtuously than the brutal that they avail. Opposite to the current understanding, Fleishman reacts reformative (Murfin, 1996, p. 105).

Other reviewers have avoided Conrad's racism question choosing to concentrate on whether Conrad was assisting imperialism or not, a foundation that relied upon and strengthened positions. Hunt Hawkins, the writer of a string of essays on the novel issued through the period 1979 1992, has seen Heart of Darkness as a criticism of Belgium's imperialist project yet its writer like a man mostly assisting British colonialism and imperialism. [In The Location of Culture (1994)], the postcolonial reviewer Homi K. Bhabha explains that Heart of Darkness perhaps located in the Belgian Congo yet " the power and presence of the English" penetrates Marlow's session as well as Conrad's (Murfin, 1996, p. 111).

The impacts of imperialism happen in numerous various types of societies overall those ' settler/invader' societies in which post-colonial appeal is solely, highly, and merely contradictory linked as it is in more clearly decolonizing regions and states. By the term, 'post-colonial' the readers do not estimate an impulsive or a seamless and unchanging procedure of opposition but a chain of connections and manifestations outside which the procedure cannot be precisely declaimed. These connections and manifestations are not constantly immediately oppositional; the material exercises of post-colonial societies may include 
a vast scale of actions involving notions and deeds which are, or manifest to be complicit with the imperial project. However, such complicit actions happen in all post-colonial societies, and their presence proposes the potential of critical similarities, which perhaps made within the whole scale of post-colonial societies. (Ashcroft, Griffiths, \& Helen, 1995, p. 3)

Postcolonial studies participate with the racial active forces of personal/individual and collective psychology in the colonial and postcolonial conditions, cultural exercises, identity, questions, nation and gender-matters, economy, and geopolitics. Frantz Fanon, psychiatrist and political intellectual portrays the earliest of postcolonial theorists who tested the cultural outcomes of colonialism and connected with racial active forces in the scopes of psychology-psychiatry, cultural exercises, and national movements contemplated around postcolonial societies. $\mathrm{He}$ offers a new humanism nearly in an exclusive manner dragged from the experiment of colonialism and subsequently a postcolonial humanism, various from the European one. Fanon signs soon the moment of postcolonial activism, thinking, and theory. His writings are constantly established in domestic situations of anti-colonial conflict but with the possibility to supply a humanist structure for reading other racialized, colonized attitudes (Nayar, 2013, pp. 2, 3). Conrad shows the kind of colonialism in Heart of Darkness. He detects the fears of colonialism and is sarcastic of the complete procedure. He employs different icon figures to achieve this. Kurtz is the major one being the gloomy and evasive who portrays Western European civilization.

\section{The Binary Oppositions in Heart of Darkness}

In Heart of Darkness, Conrad has displayed the binary opposition of self and other. He has displayed Europeans as smart, whites, superiors and cultivated. Furthermore, Africans are displayed as not clever, blacks, inferior, uncultivated, primitive, marginalized, barbaric, voiceless, and as "others". The novel is regarded as an insincere civilizing expedition of Europeans. Heart of Darkness is determined in dubious wilderness and dark. This indicates African history and the darkness of African past. Europeans think that Africans are lacking every culture and history. Africans have distorted as others by Europeans in their literary canon that is the reason Chinua Achebe, a Nigerian novelist and a literary figure of twentieth-century Africa, attempts to portray the real identity of Africans in Things Fall Apart, he has portrayed the opposing portraits of African culture. He has submitted African society conscious of its history. Conrad 
has been seen as a bigot by a few reviewers, despite his magnificent tale broadcasting. In his novel Heart of Darkness, Conrad has generated the binary oppositions among East and West. Conrad has been reviewed by Achebe for portraying East as the other world and being bigot. The novel Heart of Darkness depicted by Achebe as a "resentful and lamentable book" which "sets Africa up as a foil to Europe, as a place of negations at once remote and vaguely familiar, in comparison with which Europe's state of spiritual grace will be manifest". Achebe states that Conrad has not written it as a book of imperialism (Fatima, Jamil, \& Hanif, 2015, pp. 41, 22). Achebe suggests in his essay "An Image of Africa" that Conrad distorts his African figures so that they strengthen the conceptions of African people, environment, and savage and culture as prehistoric. This essay is a criticism of the unfavorable performance of Africa in Western culture. Achebe proposes that, in the West, there is a psychological requirement to consider Africa in codes of unfavorable opposition to Europe-that is, as a place especially uncivilized, savage, and brutal. The control of these vulgar classifications in Western culture in line renders to reconfirm Europe's position as Africa's opposite: as civilized, humane, and pure. During a mostly critical reading of Heart of Darkness, Achebe distinguishes the impact of colonialism in Conrad's fantasy. The essay has an implicit wish to amend what Achebe viewed as incorrect conceptions of Africa and to give African authors their voice (Clarke, 2017, pp. 10, 11, 12).

The result of this framework of binary oppositions is that people from colonized nations take on the unfavorable cultural patterns planned on them during works like Conrad's novel.

\subsection{Thames Versus Congo}

The novel starts on the River Thames, quiet, serene, remaining without hostility, "at the decline of day, after ages of good service done to the race that peopled its banks,"

(Conrad, 1995, p. 4). However, its current tale happens on the River Congo, the highly contradictory of the Thames. It is not applied for every sort of entertainment and services no mature-age serving trust. The readers are informed that "Going up that river was like travelling back to the earliest beginnings of the world" (Conrad, xviii). The two rivers are seen inverse to one another; one is an icon of human advancement whilst the other is the icon of uncultivated powers and crudeness. Soon, Marlow views a gathering of black individuals leading vessels in this excursion. He glorifies their simplicity, force and solidity, 
life similarities, and sensations. This concept guides him to ratify that he quiet suits a universe of intellect. The sense is for the recent time, yet, for it is not some time before Marlow, as well, reaches to view the Africans as a not quiet human state of life and to employ the language of his day indicating them as "niggers" "blacks" "barbarians" "savages" and "cannibals" (Fatima, Jamil, \& Hanif, 2015, p. 44). Displaying the opening of Heart of Darkness on the Thames enabled Conrad to betoken one of the novel's main thoughts: the deficiency of any utter fundamental variation between so-called civilized societies and so-called crude ones. "This too," Marlow says, "has been one of the dark places of the earth" (Attridge, 2018, p. 4).

The opening paragraph that appears intentionally issue of reality and actuality, "The Nellie, a cruising yawl, swung to her anchor..." (Conrad, Xv) the language speedily turns into more poetic and revealing: the Thames is "the beginning of an interminable waterway" that as we comprehend with hindsight, will guide Marlow and the reader into the heart of Africa. Words such as "The air was dark, a mournful gloom, brooding" will make several later manifestations, found a special style. Then with a magnificent economy, we will stir from the present-Victorian London "the biggest, and the greatest, town on earth" to the Roman colonists in Britain, to the Congo. This is not a bare historical scanning but a trial to bring the reality backwards the rational and emotional texts of history that were immediate: "The conquest of the earth, which mostly means the taking it away from those who have a different complexion or slightly flatter noses than ourselves, is not a pretty thing when you look into it too much" (Conrad, $\mathrm{xv})$.

Conrad is telling that the Thames and the Congo rivers are so various, one acceptable, and the other awful. Yet this isn't the genuine spot. It isn't the dissimilarity that bothers Conrad yet the hiding allusion of the affinity of popular descent. It defeated its darkness and is now in the light of day and at safety. But if it were to pay a visit it's essential akin, the Congo, it would run the horrible danger of hearing the strange resonance of its own ignored darkness and dropping prey to a revenge prevalence of the careless madness of the onsets. Those revealing resonances include famous appeal of Conrad of the African ambiance in the novel. In the last investigation, his style offset merely to a fixed, heavy, sham ceremonial recurrence of two opposite sentences, one about silence and the other concerning fury (Achebe, 1988, p. 2). For example, "it was the stillness of an implacable force brooding over an inscrutable intention" and "The steamer toiled 
along slowly on the edge of a black and incomprehensible frenzy"(Conrad, 41). Marlow says "I was thinking of very old times, when the Romans first came here, nineteen hundred years ago-the other day.... Light came out of this river since-you say Knights? Yes; but it is like a running blaze on a plain, like a flash of lightning in the clouds. We live in the flicker may it last as long as the old earth keeps rolling! But darkness was here yesterday" (Conrad, 6). Conrad indelibly, presses spots of light to kindle his major figures who then swage into the ambiguity of darkness once more.

Marlow's words indicate the time when England was colonized by the Romans. Until Roman conquers imparted civilization to England it has been an uncivilized and dark place. Marlow deduces that colonialism is defended during the expansion of civilization. In this conception cultural advance in rudimentary areas is merely reliable during the powerful taking over of developed force. The above quotation illustrates that Marlow equalize civilized areas with radiance and light whilst he connects uncivilized places with darkness. In this manner, his journey from civilized England to the uncivilized Congo can be read as a journey from light towards darkness. During the narrative light and shadow permanently exchange (Buchroth, 2015, p. 2). For Marlow, Africa portrays a previous kind of human presence. Marlow understands himself and his crew as "wanderers on prehistoric earth, on an earth that wore the aspect of an unknown planet" (Conrad, 41).

\subsection{White Versus Black}

Imperialist propaganda proposed that the white people taking charge of the station are surely not ' superior beings' or attorneys of a ' master race '. They seem as ' flabby, pretending, weak-eyed devils of a rapacious and pitiless ' to Marlow (Conrad, 18). They handle the Africans like slaves, savagely availing their work strength and contriving pretexts to punish or torment them, instead of forthright their boasted charitable expedition to cultivate and to make the natives human. Marlow changes with kindness to those tortured the utmost from the Europeans' ' fantastic invasion ', the Africans (Conrad, 26). In his planning of the horrible dealings of the blacks at the outer and central stations, Marlow's assurance is on the Africans' humanity and unhappiness rather than their assumed inferiority. In what he final summons ' the grove of death ', (Conrad, 22). He depicts the Africans as follows:

Black shapes crouched, lay, sat between the trees leaning against the trunks, clinging to the earth, half coming out, half effaced within the dim light, in all attitudes of pain, abandonment, and despair. (Conrad, 19) 
The Africans, for Marlow, seem not ' brutes ' but the Europeans. Therefore, Marlow not merely devastates, but inverses the binary opposition between the barbaric and the cultivated as engraved in the ideology of the imperialist. Marlow instinctively displays in the grove of death, "one of my good Swede's ship's biscuits I had in my pocket" to one of the dying Africans (Conrad, 19). This performance of empathy, in which he compassionately arrives at the Other, is symbolic of the way Marlow shares with the Africans. Marlow constructs piers plainly by being inquisitive and claiming questions concerning the Africans and their culture instead of, abiding by the ideologically structured gulf between the ' degenerate savage', and the white imperialists. When, for example, he demonstrates a ' bit of white worsted' restricted swing on Africans neck, he asks: "why? Where did he get it? Was it a badge - an ornament - a charm - a propitiatory act? Was there any idea at all connected with it? It looked startling round his black neck, this bit of white thread" (Conrad, 19).

The suppression of the crewmembers is more wonderful as this is a feature which the Europeans initial them Kurtz-lack: they are expended by insatiable avarice for ivory and use any chance to torment or murder the natives. When Marlow sometimes tries to fantasy his way of gazing to an African, he as well as explains his ability for sympathy. For example, he illustrates the responses of an African boy guard who raises his weapon because he slips Marlow for a white officer as "simple prudence, white men being so much alike at a distance that he could not tell who I might be" (Conrad, 18). Although Anthony Fothergill sets it, " there must be something ethnocentric in what Marlow refers to the guard', he perhaps holds ' a self-distancing capacity' which makes him capable ' to imagine what it must be like to look at a white if you're not one ' (Schnauder, 2015, p. 5). Marlow appears to consider the Africans as his equivalent: "I looked at them as you would on any human being, with a curiosity of their impulses, motives, capacities, weakness, when brought to the test of an inexorable physical necessity"(Conrad, 48). The meeting of Marlow amid the forest with the implausible white-suited worker provides him with many discursive passages, as does his confrontation afterward with the semi-crazed, harlequin-like Russian who has been so influenced by Kurtz's presents. So far implicit Marlow's delusions, his uncertainty, and short fanciful contemplations on his senses, and thoughts, is the voyage's strict 
path itself, which despite all the several hindrances, is endured during the forest, during hardship, during the time, to all its heart, Kurtz's ivorytrading empire. Conrad intends us to realize how Kurtz's big robbery venture, Marlow's voyage up the river, and the narrative itself all participate a popular topic: Europeans implementing deeds of imperial will and control in Africa (Said, 2008, p. 9).

The white men have made Africa a Dark Continent, as ironically illustrated by Conrad, paradoxically to their common portrait of attorneys of illumination. Their actions are black yet, they are white. Icons of light and darkness in the novel portray something very similar- wickedness. Marlow is capable to distinguish amidst the amplified notion of his work, and its real insignificance, amidst the passionate idealism revolving about imperialism and its economic foundation. The complete town resembles "a whited sepulcher" to Marlow. Its deathlike imputes bind to the brutality in the Empire. In scriptural expressions, "a whited sepulcher" is used as a character for some individual or somewhere whose exterior goodness and magic spread an interior defilement; henceforth, it suggests sides of the figure of the colonial countries, and this is completely real in pursuit. Conrad does not interfere with the lives of the Congolese and, from the exterior standpoint of a guest, represents them as preys of imperialism that still unknown to him. Ivory, both as an esteemed product and a color, turns into a main theme in the account. Ivory is to the Congo what silver is to Costaguana in Nostromo. It is a pure wealth such as oil and different endowments accorded upon by Nature. These blessings become the aim of people and colonial companies. Shiny and white outwardly, it is indeed a dead issue and, in this way, remains like the contrast at the center of Western human advancement. The sign of Marlow to a declining body is together objective and symbolic: native Africans and elephants together die like a consequence of the white man's chase of ivory, and the complete venture is spoiled at the center. Force especially onto other individuals, unavoidable spoils. The words "oil" and "ivory" have taken on their very own existence for the oppressor in both situation and art (Qasaimeh \& Joshi, 2009, p. 45).

To study Frantz Fanon is to experiment with the feeling of separation that prefigures and splits the development of a substantial idea that never begins without molding an ambiguous dark. His voice is ultimately heard in the ruined flip of acquainted term, in the silence of abrupt split: "The Negro is not. Any more than the white man'. The clumsy separation that fractures his line of idea retains alive the dramatic and obscure sense of the 
procedure of alternate. That usual bias of colonial subjects - Black / White, Self / Other is annoyed with one shortstop, and the conventional basis of racial personality is scattered, at any time they are set to residue in the narcissistic legends of Negritude or White cultural sovereignty (Fanon, 2008, pp. xxii, xxiii). The cliché white depiction of the black and making them smaller to creatures is Marlow's image of his riverboat's boiler as he comments: "to look at him was as defying as seeing a dog in a parody of breeches and a feather hat, walking on his hind legs" (Conrad, 42). Africans cannot be altered. They can merely be spoiled or devastated. In the same strain, the rehearsal dolls with "Manichean" binary partition of light and dark by referring to favorable feelings to the previous malevolent and fearful notions to the end. That white-black binary is not very considerably frosted as it demonstrates to be changeable and changing. So that, for the present, this due opposition specifically creates the feeling as the influencing thought innate complete to the colonization's cultural pursuits and in the psychology. What's more, it is this plain, but smart thought that warranty the colonialist's supremacy and conducts to the subordination of the colonized; it authorizes the white declare quite to move ultimate outgoing their domain and oppress together natives and their territory for exploitative goals. Marlow illustrates that he is "something like an emissary of light, something like a lower sort of apostle" (Conrad, 14) although he confesses "[his] head has nothing in it but that wretched steamboat business". (Conrad, 28) Correspondingly, one of his mate companions in reply to why he has come there answers "to make money, of course. What do you think? He said scornfully" (Conrad, 23).

The impedance of the native to colonial dominance and violation is not considered like their truth yet like an abnormality of brutality that happens at most by force and should be suppressed and cultivated outside control. The initial model of this natives' impedance onto the colonizers is in the fight which begins over two black hens; although the son of the head of the provincial murders the master of the combination, his response is minimal a deed of fierceness than that of guardianship (Conrad, 9). Another example is the scenery of the offense of Marlow's helmsman and ship, which demonstrates to have been induced by Kurtz, the white head of the "Inner Station" (Conrad, 29).Yet through his excursion, Marlow and his staff are frightened of the native's possibility offense considerably subsequent meeting with Kurtz till he dies (Sasani \& Molaii, 2015, p. 138). 
The responses of the whites to the capability of native offense display a paradox to that of the cannibals. The previous is "greatly discomposed" (Conrad, 47). On the other hand, the "black fellows" (Conrad, 74) are "essentially quiet" (Conrad, 47). What does Conrad propose by this paradox? The cannibals, probably more ferocious than the civilized whites, offer a whimsical suppression "one of those human secrets that baffle probability" (Conrad, 48). Hungry as they are, they do not eat their white employers. They have a code. Contradictory, the pilgrims explain opposition harmful loose moral floss that imprints them as less civilized in simile with their black slaves. These whites have no ethics, no code. So far Conrad once more calls the natural law: the whites here are entirely "detribalized" - and demoralized- lot. The cannibals belong here and act out a social law of restraint and work. The pilgrims scare an offense. But for Marlow, "the danger, ... was from our proximity to a great human passion let loose" (Conrad, 50). The "passion" is in the heart's center. When let free it may result in violence. What Conrad proposes in this typically indirect declaration is that when the evil in every heart's center slots itself without restraint, it offers one or two kinds of evil duality: the loose manager of the pilgrim kind or the violent Kurtzian kind.

\subsection{Light versus Dark}

For Marlow, the images of light and dark and their combined feelings flicker so repeatedly and paradoxically that the entire notion of light and dark and their general partition become upside down-chaos by the end. From the start, the darkness fluxes to some extent abroad there in the perfect brutality, the wild that moves in the timberland, in the scrublands, in the hearts of wild men, vague, malevolent, or set other path runs in the physical darkness of the natives, their territory and their wretched life. Light escorts health, whiteness, and European human advancement on the opposite side. This is to state, up over, various images are intensified inside a solitary picture whether, dark or else. Yet these notions are especially connected to the visible orientation of the dream rehearsal. Since light and dark on minor standards indicate the binary partition of white and black with entire connective feelings formerly argued as whole to colonialism's both ideology and psychology. As the rehearsal stirs moreover, it targets its trend towards light images, although the dropping of interior darkness over external components go on to the furthest limit of the excursion; there are minutes when whiteness and mist are portrayed as warm as darkness and even a hindrance to the scene of the darkness itself (Sasani \& Molaii, 2015, 
p. 140). Yatzeck indicates to such goodness like "blind whiteness" (Conrad 49) however, he illustrates that light is an instrument of deception in this novel, and it is not to "illuminate darkness" yet it could be said, it is the darkness itself. Here is an example of this blind whiteness in Marlow's words: "Well, you may guess I watched the fog for the signs of lifting as a cat watches a mouse; but for anything else, our eyes were of no more use to us than if we had been buried miles deep in a heap of cotton-wool". (Conrad 50). It should be renowned that white and dark images in their imperialistic ideological feeling for the aim of marginalizing and Othering the natives are copious during the rehearsal on the facile. Merely in one case, this light-dark duplicity is blended, and this happens completely at the end of the excursion inside the heart of darkness, the immediate that Marlow occurs to halt versus Kurtz. At this level, the previous concentration of cultivation and the advanced into crudeness and whiteness and the rudimentary into darkness is overthrown and blended to have all the previous binary images concentrated into a stained whitish dark and opposite (Sasani \& Molaii, 2015, p. 141).

"Darkness" appears to intervene in the novel. Marlow's story starts and finishes in textual gloom; the onset of the novel is overwhelmingly dim, like when the steamship is punched in by mist or when Marlow restores Kurtz; dark-skinned persons dwell the complete area; and certainly, there is a confirmed philosophical gloom that penetrates the task. Through Marlow's expedition to locate Kurtz, he is as well as attempting to locate himself. He, such as Kurtz had good connotations upon getting in the Congo. Conrad attempts to display us that Marlow is what Kurtz has been, and Kurtz is what Marlow could become. Every human has a little of Marlow and Kurtz in them. Marlow illustrates concerning himself, "I was getting savage", meaning that he was becoming more like Kurtz. Forever the voyage into the wilderness, they find out their real selves during the connection with savage natives (Song-cun, 2017, p. 117).

Marlow's previous captain Fresleven had been killed in a scuffle with the natives. Fresleven's struggle with the natives emerge from an incorrectly understanding concerning two black hens, he disputed he was beguiled in the deal, and then he defeats the chief of the village without mercy. In the end, the chief's son killed him in despair at hearing his father scream. Here Fresleven appeared as a savage ruler, not as a civilized man. There are oppositions during the colonists, when the director proposes that the "scoundrel" who is doubtful of aiding Kurtz obtains his ivory, ought to be executed like an instance, his uncle corresponds. These deeds are 
capable in the Congo, an area far from the illumination of a cultivated deed. Furthermore, Kurtz's utmost bothering performance, the status of human heads at the top poles around his station house, is merely capable in the hidden Congo. Here secluded from the residue of his society, the colonists became inclined by his power and isolation. In the colonists, the dark side concealed obviously. Kurtz dies at the end, and screamed "The horror! The horror" (Conrad, 90). When Kurtz completes his last words; he recognizes the horrors that he has done, society goes on the evil exercise of its imperialistic exploitation and prison outwardly equal a suggestion of discussion minimal savage styles. Yet Kurtz's last declaration indicates extremely to Marlow, he views it as a society's assessment, also Kurtz's soul. The horrors are real and sensible for Marlow; he recognizes the declaration of Kurtz since he has seen models of horrors with similar kinds. Whilst Kurtz goes onward in returning to barbaric paths, Marlow has realized a highly significant warning that he will hold with him for the residue of his life. Kurtz's words are an assessment and a caution for Marlow; they are words adhere to. Shortly, Marlow senses that Kurtz may be a portion to all mankind and is a portion of him. Marlow would always recognize and gain from Kurtz's horrors (Song-cun, 2017, p. 118).

The novel is another such catachrestic prosopopoeia, to give its ferocious-resonant. Greek eloquence name - we venture our bodies on embracing objects and on the scenery. We give darkness a heart. Prosopopoeias are a major means of naming by indirect course in Heart of Darkness, what Conrad recalls, in unsuitable and a deceptive allegory, "the darkness," or "the wilderness," or utmost plainly and may be utmost honestly, "it" (Miller, 2008, p. 119). The wilderness embracing the Central Station, states Marlow, "struck me as something great and invincible, like evil or truth, waiting passionately for the passing away of this fantastic invasion" (Conrad, 26).

\subsection{Wilderness Versus Civilization}

By a style of demonic temptation, the wilderness decays Kurtz: "The wilderness had patted him on the head, and behold, it was like a ball -an ivory ball; it had caressed him, and -! O! he had withered; it had taken him, loved him, embraced him, got into his veins, consumed his flesh, and sealed his soul to its own by the inconceivable ceremonies of some devilish initiation. He was its spoiled and pampered favourite" (Conrad, 56). The Africans disappear at Kurtz's Inner Station, "without any perceptible movement of retreat, as if the forest that had ejected these beings so 
suddenly had drawn them in again as the breath is drawn in a long aspiration" (Conrad, 70).

In Heart of Darkness, the final reference indicates another and not uncertain capable merit of the performance. The wilderness's incarnation is identified by an identical conversion of the African people, who interfere among Marlow and the "it". In the novel, all the Africans Marlow faces are icons and visual attorneys of that "it". Although it perhaps racist for Marlow to view the Africans as a mysteriously "other" as plain "savages" or "primitives," once their culture is ancient than any European one and as sophisticated or complex, if less therefore, this otherness is tired of the initial aim to make the Africans visual incarnations and evidence that the "it" the darkness is a person (Miller, 2008, p. 120). This can be implicit merit of every prosopopoeias of Marlow, however it's created utmost clear in the scenery wherever African mistress of Kurtz manifests atop the shoreline:

\footnotetext{
She was savage and superb, wild-eyed and magnificent; there was something ominous and stately in her deliberate progress. And in the hush that had fallen suddenly upon the whole sorrowful land, the immense wilderness, the colossal body of the fecund and mysterious life seemed to look at her, pensive, as though it had been looking at the image of its own tenebrous and passionate soul.... She stood looking at us without a stir, and like the wilderness itself, with an air of brooding over an inscrutable purpose. (Conrad, 71)
}

This section, such as the one characterizing the manner the wilderness has tempted Kurtz, appears to illustrate that this "it" is gendered a feminine, a huge main part of fruitful and ambiguous life. Since wilderness is suggested to portray ambiguous understanding, "like evil or truth," such incarnation does not deviate so quite with the "sexist" confirmations Marlow creates concerning the path women in common are similar to Kurtz's Intended, "out of it", unaware and undefeatable honest (Miller, 2008, p. 121).

Marlow confirms forever, that although Kurtz was a global mentality, musician, artist, politician, journalist, and so on, his major distinctive was his language's talent: "A voice! a voice! it was grave, profound, vibrating, while the man did not seem capable of a whisper"(Conrad, 70, 71). "Kurtz discoursed. A voice! A voice! it rang deep to the very last. It survived his strength to hide in the magnificent folds of eloquence the barren darkness of his heart" (Conrad, 80). Kurtz, shortly, has a wonderful language control 
which resembles Conrad's or Marlow's own. "An appeal to me in this fiendish row-is there? Very well; I hear; I admit, but I have a voice too and for good or evil mine is the speech that cannot be silenced" (Conrad, 42).

Kurtz's name means short and everything concerning him was short: his repute as a rhetoric speaker, his profession as an ivory agent, and his life also. So far, his impact on some specific people continued for a lengthy period. For instance: Marlow considered the voyage towards Kurtz as a continued nightmare that wouldn't vanish from his mind: and Kurtz's Intended was remain in wail one year after his death, what's more, she told Marlow that she would live with Kurtz's final words, which was merely a lie by Marlow. It is normal but repents that this man didn't obtain his joy after working so harshly. Of course, he was cruel and bleeding both to the whites of a lower situation like the Russian and to the natives. Yet compared with those who got rich during the ivory he gathered at the danger of his life and conscience, he was the one deserving of the reader's empathy. Marlow was the merely one there that showed big empathy to Kurtz, particularly when he saw that Kurtz was struggling with his evil soul that knew no suppression, no content, and no scare and at that time, he surely confirmed that the seduction of the wilderness made Kurtz's cruelty and devastated his soul, so he attempted to fracture the spell of the wilderness. So far, Marlow could not alter Kurtz's fate of being swooped by the wilderness, which was controlled by the time Kurtz made his resolution of being the messenger of civilization to dark Africa. Yet, we feel very repentant for Kurtz because he was the prey of history and the aims of colonization and servitude that he had dedicated himself to have been manifested wrong by time (Zaho, 2008, p. 149).

Through the Congo excursion, Marlow turns out to be more conscious of things, yet he currently views those delusions are important for existence. The final words Kurtz declared opposite to what Marlow says to the Intended, were not her name yet "The horror! The horror! ". Marlow needs to scour his path through the carnage and brutality in the wild of the Congo to accomplish illumination. Marlow observes Dark Continent, which has an emblematic significance. It is the observation with the powers of darkness as incarnated in the crude individuals of Congo. Afterward, Marlow practices a different aspect of darkness (Qasaimeh \& Joshi, 2009, p. 47). At the point while he goes to the wild, he declares: "I felt an intolerable weight oppressing my breast, the smell of the damp earth, the unseen presence of Victorians corruption, the darkness of an impenetrable night" (Conrad, 73). 
Distances in Africa are very wide, the environment and the isolation very unbearable to Europeans, nothing good can be foreseeable of European rule. In Conrad's tale, it is merely the dimensions, the environment, and the isolation that break down the two Europeans. Utmost of all the isolation, for that inheritance as well as an inner eagerness, Conrad writes; they lost something that formerly "had kept the wilderness from interfering with their heart". "The images of home, the memory of people like them, of men who thought and felt as they used to think and feel, receded into distances made distinct by the glare of unclouded sunshine". Isolation removes society from within them and abandons backwards scare, disbelief, and fierceness (Lindqvist, 1992, p. 26).

The trappings of civilization in Africa are trivial, oblique, without object uninteresting of railroad structure; propose some object weird, and a boiler blundering in the weed. Readers' disability to slay the old hippo with their guns moves the feeling of an impervious wildness. In a similar manner, the French ship edge into the jungle appears sterile and inane: "There was a touch of insanity in the proceeding, a sense of lugubrious drollery in the sight; and it was not dissipated by somebody on board assuring me earnestly there was a camp of natives -he called them enemies- hidden out of sight somewhere" (Conrad, 16). Marlow characterizes the plant woods of Central Africa as the unclear and impervious sea. The amendment is not merely sterile, but deadly: "The edge of a colossal jungle, fringed with white surf, ran straight, like a ruled line, far, far away along a blue sea whose glitter was blurred by a creeping mist" (Conrad, 14). The results of development are destroying for Conrad. For all sides, the confrontation of wilderness and civilization is dreadful. The conversation attends disaster for the Negroes, madness, and death; for the whites, the destruction after Fresleven's death exposes this "the huts gaped black, rotting, all askew within the fallen enclosures. A calamity had come to it, sure enough" (Conrad, 10). Marlow permanently experiments struggle among the falsity of his civilized psyche and the horrible demolition he testifies "For a time I would feel I belonged still to a world of straight forward facts, but the feeling would not last long" (Conrad, 15).

Marlow induces our social typical criticism: "He must meet the truth with his own true stuff-with his own inborn strength. Principals won't do" (Conrad, 42). Marlow's dance with the boilermaker exposes the confines of prompted self-refinement which means the contradiction of the typical. Marlow confirms an especial new part of literature: idealism is not realism, however a reversal of the living world in all its mistakes (Catherall, 2013, 
pp. 4, 5). White employees oblige the Congolese to do slave work using torment that is why they could not even interact, the excursion of Marlow can be regarded as a frightening dream because of what he had seen there from starvation, illness, natives who had been exploited or lashed or even killed through millions at a time. In Heart of Darkness, there is a sign to complete refusal of every cultivation in Africa since Europeans confirmed that Africa and Africans in common were uncultivated which indicates inversely or rudimentary individuals that is why Marlow qualified his trip like an excursion behind on time as he had said: "going up that river was like travelling back to the earliest beginning of the world" (Conrad, 39). Thus, the British adopted every kind of racism to gain what they need which drove to the abuse of force that inverted the wickedness of colonialism (Sharmin, 2018, p. 4).

\subsection{Modern Versus Barbaric}

Another opposition is found in the novel, Kurtz does not oblige the natives at the Station to work for him by cuffs and chains, yet frightens them by "thunder and lightning" (Conrad, 66) (which are just guns and bullets) and progressively controlled them spiritually so they work and die for him voluntarily. Kurtz's big impact upon the natives comes immediately from his property of new weapons like rifles and shots, which the natives have never seen before; they take the fires' rifles as "thunder and lightning". The African natives' feebleness is that they do not possess new weapons; shamefully, Kurtz takes this feature and frightens the African natives to make them loyal to him. So, he can handle them in his chase for ivory in other villages (Song-cun, 2017, pp. 118, 119).The heads of "criminals" constant on the dowels embracing Kurtz's lodging are an amazing proof of the famous means of the threat he employs upon the African natives. "These heads were the heads of rebels. I shocked him excessively by laughing. Rebels! What would be the next definition I was to hear? There had been enemies, criminals, workers, and these were rebels. Those rebellious heads looked very subdued to me on their sticks" (Conrad, 68, 69).

\subsection{Superiority Versus Inferiority and Other (them) Versus Us (self)}

Heart of Darkness shows racists confirm that human beings separate races, they as well as confirm that the various races are either superior or inferior. The superior races are allowed to exploit, control, and devastate anyone belongs to an inferior race. Members of inferior races are not seen as persons or as human beings with feelings at all. Europeans introduce 
Orientals as barbaric, innate, savages, oppressive, strange and uncivilized others. To vindicate the performance of colonialism, the natives considered as barbarians by the Europeans. Keith Booker illustrates that the exemplification of Africans as barbarians causes the Europeans to appear cultivating and as well as explores the Europeans' superiority onto African natives. When Marlow observes six Africans obliged to work with chains about their necks, he does not attempt to intervene or oppose them. He summons what he views it in their eyes as the "deathlike indifference of unhappy savages" (Conrad, 18). He portrays them as savages, uncivilized, and barbaric. He states concerning a black African that he was "a savage who no more account than a grain of sand in a black Sahara" (Conrad, 59). Thus, in this course, native Africans have been displayed by Conrad like savages, brutes, barbaric, slaves, and uncivilized, and in disparity, he has introduced Europeans as intelligent, masters, and civilized. Conrad was a bigot who describes the inferiority of Africans, and the superiority of the Western imagination. He would overwhelmingly blend unawareness with racism when he characterized the natives by saying that, "They howled and leaped and spun and made horrid faces, but what thrilled you was just the thought of their humanity-like yours- the thought of your remote kinship with this wild and passionate uproar. Ugly" (Conrad, 41, 42).

The novel can be understood like a tale of a man who confronted many political, spiritual, and moral terrors. Congolese were patronized like slaves: the white man here and there attempted to contrive pretexts to chastise or torment them since they were experts and predominant. In this depiction, Marlow pressed on the misery of the Africans since they were alive genuinely, however ethically dead as shadows. Also, each declaration in Heart of Darkness mirrored the misery of the Congolese who were obliged to work under the dominance of the white master received a wide range of racism and violence so that to scare or murder the Africans. In the novel, Congolese had no names; they were merely dead individuals, or shadows or black shapes anguish famine and disease: "They were dying slowly.... It was very clear...." (Conrad,19).

Marlow tells about the savage staff: "Fine fellows -cannibals- in their place" (Conrad, 40). Marlow as well as dissuades for their suppressions. He said that these savages were of a preferable kind. Although they were starving, but they did not eat human flesh. This kind of relinquishing dissuade by Marlow is completely uncalled and unwanted. During this Marlow desires to build his racial predominance on the black Africans. Latest when Marlow's helmsman is murdered in the trap, Marlow has 
readily pushed his body onboard so that to hinder a barbarian bash on the boat. It proposes that although Marlow dissuades savages, in his internal mind he realizes these savages can take human flesh. In this course, Africans are methodically oppressed, dehumanized, and decadent. It is discussed that one of the causes for savagery in the western conversation in Africa to prevail was to vindicate Africans to be rudimentary, and so, they must be colonized and socialized (Sharmin, 2018, p. 6).

Guven (2013) illustrates that when the natives equaled to the Europeans they are viewed as inferior and this is the only reality for them, yet Conrad suggests that this rejected during the novel over after his experiments in Africa disagree with the general doctrine concerning colonialism in England. Marlow is selected by Conrad to illustrate the European colonialism actualities, that is, natives' position told during Marlow, a European as well as. In other words, he chooses a fantastic figure to detect reality rather than himself. Keith Booker illustrates that "Conrad's Charlie Marlow is openly critical of much of the European activity that he observes in Africa, especially of the brutal treatment of many of the Africans by their European masters" (p. 85). (Aydin, 2018, p. 233) illustrates that in the novel, the portrait of Africa represented like another universe's portrait, which is a contrast to western civilization. In other words, it is the conversation between 'Self / Us' and the 'Other / Them ' as delineated by Achebe:

Heart of Darkness projects the image of Africa as ' the other world, ' the antithesis of Europe and therefore of civilization, a place where man's vaunted intelligence and refinement are finally mocked by triumphant bestiality (wildness) (Chinua Achebe, 1978: 3)

The priority is given to European superiority instead of treating both European and African esteem in the same way. Charlie Wesley illustrates that "Much of the criticism that surrounds this novella [...] is focused on the European subjects of the text, and therefore renders Africa and its native peoples as a kind of backdrop". Edward Said sets upwards the notion that European superiority or control neglects the 'Other / Them and adopts a western point of view which allows Kurtz's imperial deeds ' (Aydin, 2018, p. 234).

The novel depiction of the "other" can be viewed during the racial difference between the self (civilized, white, Europeans) and the other (black, savage, other). The colonizers thought that the colonized were at the margins and they are at the core of the world. The colonizers thought 
they are appropriate "self;" while native people were regarded inferior and "other". Othering is called for the exercise of all who are various under absolutely human and it separated the world amid "us" (the civilized) and "them" [the "others" or "savages"]. The "savage" is generally condemning regarded as evil also as inferior (the demonic other). But occasionally the "savaged" is understood as retaining a "primitive" charm or loyalty born of a nearness to nature (the exotic other). In each status, however, the "savage" abides alternative so that, not completely human beings (Tyson, 2006, pp. 419, 420).

As for Kurtz's feeling of the horror of it all, there can be no horror, merely comfort, in the consent which the death lead delivers us to. Yet for Marlow and Kurtz grasped almost between declination and the death drive, there is residue horror in the tempting conversation with non-being. Regard again Conrad's tale in the kindle of the political question which has been demanded with a growing instance in current times: is it a racist text? In Conrad's vindication, it has been said that he shows either immediately or sarcastically, the cruelty of imperialist imposition in Africa. As well as that he harshly undermines the suggested superiority and variation of the civilized to the rudimentary even to the extent of breaking down the one into the other. And that is significant, particularly at the time of the novel's manifestation when such suppositions of superiority were strongly energetic in the ideological vindication of imposition. This combining or breaking down of the supposed variations between Africa and Europe, the civilized and the primitive, is, as we saw, substantial to the contradictory nature of Kurtz. But the problem goes deeper (Dollimore, 2012, pp. 77, 78).

"The vulnerability" of the colonizer, for Homi K. Bhabha lies at the very origin of his "narcissistic demand" that he ought to be "addressed directly" and that "the other" should "authorize the self" by understanding its superior situation during the rehearsal of its fundamental allusions whilst he "still his fractured gaze" (Schwarz, 2005, p. 458). As a result of this narcissistic intelligence obtains its legality during the variation between the self and the other it will conduct in a dyadic order of mimicry. "Mimicry" is a "strategy of power as well as resistance" founded on "cultural difference" which promotes the colonized tradition of the colonizing requests and demands them to reflect the picture of submission whilst at the similar time it prompts defy and impedance to the "universal values" of western belief system (Schwarz, 2005, p. 459). This connection between the prevailing and the inferior culture is not "antagonistic" to the 
same extent as it is "agonistic". This is the reason why Marlow turns between tortures for the forfeit of his helmsman on the one hand and terror which makes him send away his body on the other. The "ambivalence which each [the colonizer or the colonized] feels towards the other contains some measure of desire and both are in some ways mutually in need of each other" (Schwarz, 2005, p. 461).

In words of Bhabha, Mimicry proposes a "strategic reversal of the process of domination... that turns the gaze of the discriminated back upon the eye of power" (Schwarz, 2005, p. 459). Luckily, within the kindle of this feeling of mimicry discontent of Marlow beneath helmsman's the defying stare turns into widely obvious. Marlow previously uncovers anxiety at the scene of the injured man's "black death-mask" which blew him for "inconceivably somber, brooding and menacing expression" (Conrad, 54). Finally, only by his reckoning, it turns into obvious such fundamental cause for the leaning of the helmsman's body overboard was not cannibals' scare who would possibly have eaten him (Conrad, 60) to some extent it was because "[he] had to make an effort to free [his] eyes from [the helmsman's] gaze and attend to the steering" (Conrad, 54).

The European Other consists not merely of black men but as well as women. Although this is implied elusive topic Marlow's position toward women in few examples once more mirrors the percipient superiority to his sex and the inferiority of women. The conversation that has been nurturing and shaping the image of the Other was not merely black-oriented but anything that could menace the virility of man control. Marlow illustrates that he went to call his aunt for help. "... I tried the women. I Charlie Marlow, set the women to work - to get a job. Heavens! well, you see, the notion drove me."(Conrad, 9) this ideology has increased in Africa with a little amendment. The percipient European self must overcast any Other.

One can say that the victory is the moment when the human being confesses his mistakes and believes that there is no distinction between all mankind to reach a point of self-realization that the evil practices and darkness are in his soul and he should free himself from these chains to live a life without misery. In the Holy Quran, in surah Al Hujurat Ayah (11) it says that "In the Name of Allah, the Merciful, the Most Merciful, O you who believe, let not people laugh at people, perchance they may be better than they; nor let women laugh at women, perchance they may be better than they. Neither find fault with your own people, nor call one another by nick-names. Evil is a bad name after faith; and whoso turns not, these it is that are the iniquitous" (Electronic Quran). 


\section{Conclusion}

In the history of English literature, Joseph Conrad is regarded as one of the premium novelists. He lived a life that is in direct contact with massive powers of history. From this point of view Heart of Darkness sounds important, indispensable, and the outcome of dark historical powers that goes on to form our modern world. One can conceive people look at the cultures of others through Heart of Darkness. Conrad testified about the insanely colonial growth of the British Empire. The extension and exploration of colonial literature have its superiority. Heart of Darkness reveals the attack on colonialism, and colonialists' duplicity and greed. It likewise discloses the senseless Western racial differentiation, the disenchantment of civilization, and the dark side of human nature. It is a blending of psychological, political, and social sarcasm.

The novel expels to be so much of "mixed" things and by denying to provide its visibility to a single point of view (the story is told by two narrators, neither of whom endeavors to repress the other's voice, or the other figures' voices, pressing on blending a method of submitting that is extremely factual and deeply symbolic. It is the strength of combining opposites to make the reader understands actuality and the symbols that make us sure of the passions of the heart and also the deep reality of fiction. Conrad writes this novel to make the Europeans understand the truth of colonialism which is murder and robbery for him. He denounces the evil imposition of colonialism which is enforced on Africa by England. This novel displays the Africans' misery and distress raised by European colonization. It concentrates on the ethical struggles of European investigation of Africa. Conrad compromises in what way a cultured man transforms into a brutal when the gains are seized into foresight. Europeans consider Africans as sour and rudimentary that's why they colonize them. This novel compromises the harsh relation among the natives and the Europeans.

In opposition to colonial masters, Marlow does not understand the African people as inhuman and uncultivated. He does not strain the variation between Europeans and Africans but their affinity. The novel compromises the binary oppositions between the colonizer and the colonized. The procedure of othering is at the very core of the novel. The European, the central part of the imperialist ideology is on the top and the Africans on the bottom. Through the journey of the binary oppositions in Heart of Darkness, Marlow realizes that the actual darkness lies in the 
heart of a white man and not in the Africans. At the end of the novel, Marlow returns to Europe with the experience of the alienated and an outsider society. He reaches the moment of self-knowledge and realizes that evil and good permit him to become completely aware of what it means to live; he acquires redemption as an individual after his conflict to confront the Satanic evil that he finds in Kurtz. What is significant in this novel is not only to uncover man's past but also to define his future.

One thinks that it is impossible for any strong individual to rule the whole world and puts it under his control. One day the poor people will rebel and gain their freedom from the domination of different doctrines and ideologies. One should permeate the hearts that beat in the darkness and believe that there is no difference between the white man and the black man, no difference between people except by good deeds. The Messenger of Allah, Muhammad (peace be upon him) said "Allah does not look at your figures, nor your attire but $\mathrm{He}$ looks at your hearts and accomplishments" and The Messenger of Allah, Muhammad (peace be upon him) also, said, "There is no difference between the Arabic and Aagami, not between white and black but except by piety".

\section{References}

Achebe, C. (1988). An Image of Africa: Racism in Conrad's Heart of Darkness, Massachusetts Review. Retrieved from https://polonistyka.amu.edu.pl/...pdf/Chinua-Achebe.An-Image.of.A...

Ashcroft, B., Griffiths, G., \& Tiffin, H. (Eds.)(1995). The Post-Colonial Studies Reader. London \& New York: Routledge.

Ashcroft, B., Griffiths, G., \& Tiffin, H. (Eds.)(1998). Key Concepts in PostColonial Studies. London \& New York: Routledge.

Attridge, J. (2018). How Conrad's imperial horror story Heart of Darkness resonates with our globalized times . Retrieved from Theconversation.com/how.conrads.imperial.horror.story.heart.of.darkness .resonates.with.our. globalised.times.94723.

Aydin, A. (2018). A Eurocentric Reflection in Joseph Conrad's Heart of Darkness. Journal of History Culture \& Art Research, 7(2), 230 - 238.

Buchroth, A. (2015). Joseph Conrad's Heart of Darkness. The Display of Victorian Values in a Context of Crisis. Retrieved from https://www.grin.com/document/351090. 
Catherall, p. (2013). Is Heart of Darkness Ultimately a rejection of imperialism's authorized Lies. Retrieved from www.draigweb.co.uk.

Clarke, C. (2017). An Analysis of Chinua Achebe's an Image of Africa: Racism in Conrad's Heart of Darkness. London: Macat International Ltd.

Conrad, J. (1995). Three Novels Heart of Darkness, The Secret Agent, and The Shadow Line edited by Norman Page. London: T he Macmillan Press LTD.

Dollimore, J. (2012). Civilization \& its Darkness in Conrad's Heart of Darkness and Contemporary Thought: Revisiting the Horror with LacoueLabarthe,(ed.) Nidesh Lawtoo. London: Bloomsbury.

Fanon, F. (2008). Black Skin, White Masks. United Kingdom: Plato Press.

Fatima, A., Jamil, A., \& Hanif, S. (2015). Othering of Africans in European Literature: A Postcolonial Analysis of Conrad's Heart of Darkness. European Journal of English Language and Literature Studies, 3(5), 40 45.

Firchow, P. E. (2000). Envisioning Africa: Racism and Imperalism in Conrad's Heart of Darkness . Lexington: University Press of Kentucky.

Guven, S. (2013). Post-Colonial Analysis of Joseph Conrad's Heart of Darkness. Journal of History, Culture and Art Research, 2(2), 79 - 87.

Lindqvist, S. (1992). Exterminate all the Brutes. New York: The New Press.

Miller, J. H. (2008). Should We Read Heart of Darkness? in Joseph Conrad's Heart of Darkness: Bloom's Modern Critical, Interpretations. Harold Bloom (Ed.) . New York : Infobase publishing.

Murfin, R. C. (Ed.) (1996). Heart of Darkness : Joseph Conrad. New York: Palgrave Macmillan.

Mustafa, S. O. (2018). Critical Study about the Colonialism in Heart of Darkness. Retrieved from http://owication.com.Humanities-Literature.

Nayar, P. K. (2013). Frantz Fanon. London \& New York: Routledge Taylor \& Francis Group.

Peters, J. G. (2006). The Cambridge Introduction to Joseph Conrad. New York: Cambridge University Press. 
Qasaimeh, Y. A., \& Joshi, M. (2009). Journey from the Heart of Darkness to the Heart of Sadness: Fiction V/S Reality. International Journal of Psychological Studies, 1(1), 42-50.

Rizzo, M. (2003). Marlowe's Questionable Racism: The Struggle between Human Sentiment and Nurtured Principles. The Review: A Journal of Undergraduate Student Research, 6, 1 - 7.

Said, E. W. (2008). Two Visions in Heart of Darkness in Joseph Conrad's Heart of Darkness: Bloom's Modern Critical Interpretatoins. Harold Bloom ( Ed.). New York: Infobase publishing.

Sasani, S., \& Molaii, E. (2015). Darkness in the Costume of Whiteness: a glimpse of black gaze, white mask in Heart of Darkness. International Letters of Social and Humanistic Sciences, 49, 135 - 145.

Schnauder, L. (2015). Marlow's Journey in Conrad's Heart of Darkness: Crisscrossing the Boundaries of Imperialist Ideology and Epistemology . Retrieved from eSharp, Issue 4 Journeys of Discovery. Marlow's journey in Conrad's... Imperialist Ideology and Epistemology .

Schwarz, H. \& Ray, S. (Eds.)(2005). A Companion to Postcolonial Studies . Malden: Blackwell.

Sharmin, S. (2018). Racism in Conrad's Heart of Darkness: A Critical Investigation. American Research Journal of English and Literature, 4(1), $1-8$.

Song-cun, Z. (2017). On the Three Themes of Heart of Darkness. Sino-Us English Teaching, 14(2), 116 - 119.

Tyson, L. (2006). Critical Theory Today: A User-Friendly Guide, Second Edition. New York: Routledge, Taylor \& Francis Group.

Zaho, J. (2008). The Tragedy of Kurtz: An Analysis of Kurtz in Heart of Darkness. Asian Science Journal, 4(6), 148 - 150. 